\title{
Çiğ ve UHT Sütlerinde Kimyasal Parametre Değişimlerinin Tespiti
}

\author{
Mustafa Güçlü SUCAK ${ }^{1 *}$, Oğuz AĞYAR ${ }^{1}$, Ahmet ÖZKAYA², Eray YILMAZ \\ ${ }^{1}$ Adıyaman Üniversitesi Kahta Meslek Yüksekokulu, Veterinerlik Bölümü, Adıyaman, Türkiye \\ ${ }^{2}$ Adlyaman Üniversitesi, Fen Edebiyat Fakültesi, Kimya Bölümü, Adıyaman, Türkiye \\ (ORCID: 0000-0001-6147-470X) (ORCID: 0000-0002-6107-894X) \\ (ORCID: 0000-0002-0173-3084)(ORCID: 0000-0001-7696-9174)
}

\begin{abstract}
$\ddot{O} \mathbf{z}$
$\mathrm{Bu}$ çalışma, çiğ ve ticari UHT inek sütlerinin bazı biyokimyasal parametreler yönünden karşılaştırılması amacıyla yapıldı. Bu amaçla, süt numunelerinin mineral ve kimyasal bileşen parametre seviyeleri, sırasıyla İndüklenmiş Eşleşmiş Plazma Atomik Emisyon Spektrofotometresi (ICP-OES) ve Foss Electrik (FT-120) süt analizörü cihazları kullanılarak ölçüldü. Doğal inek çiğ sütleri Muş Bölgesinden temin edilirken, ticari amaçla üretilen UHT sütleri Adıyaman ilindeki yerel marketlerden temin edildi. UHT sütleri tam yağlı ve yarım yağlı olarak iki gruba ayrıldı. Çiğ süt minerallerinden kalsiyum $(\mathrm{Ca})$, demir $(\mathrm{Fe})$, mangan $(\mathrm{Mn})$ ve fosfor $(\mathrm{P})$ düzeylerinin ticari sütlere göre daha yüksek çıktığı belirlendi. Ayrıca, çiğ süt kimyasal parametrelerinden yağsız kuru madde, yağ ve protein düzeylerinin de daha yüksek çıktığı gözlendi. Çalışma sonuçlara dayanarak, ticari inek sütlerin besinsel düzeylerindeki azalmanın insan sağlığını etkileyebilecek oranda olmadığını düşünmekteyiz.
\end{abstract}

Anahtar kelimeler: Çiğ inek sütü, mineral, ticari süt, protein, yağ.

\section{Determination of Chemical Parameter Changes in Raw and UHT Milks}

\begin{abstract}
This study was done to compare raw and commercial UHT cow's milk with in terms of some biochemical parameters. On the basis of this aim, mineral and chemical parameter levels of the milk samples were measured by Inductively Coupled Plasma Atomic Emission Spectrometer (ICP-OES), and Foss Electric (FT-120) milk analyzer, respectively. While natural cow raw milks were obtained from Mus region, UHT milk produced for commercial purposes was obtained from local markets in Adiyaman province. UHT milks were divided into two groups as full fat and half fat. It was determined that the levels of calcium (Ca), iron (Fe), manganese (Mn) and phosphorus $(\mathrm{P})$ were higher in raw milk than in commercial milk. In addition, the levels of fat-free dry matter, fat and protein were also observed to be higher in the chemical composition parameters of raw milk. Based on the results of the study, we think that the decrease in the nutritional levels of commercial cow milk is not at a rate that may affect human health.
\end{abstract}

Keywords: Raw cow milk, mineral, commercial milk, protein, fatty.

\section{Giriş}

Dünyada yoğun olarak kullanılan gıdalardan biri olan süt, birçok hayvan türünden elde edilmektedir. Dünya genelinde sütün \% 85'i inek, \% 12'si manda, \% 2.3'ü keçi, \% 1.4'ü koyun ve \% 0.2 'si deve sütünden temin edilmektedir [1]. Süt içeriğinde bulunan kazein, laktoz, esansiyel yağ asitleri, vitaminler ve mineraller insanlar için yüksek besin değeri sağlamaktadır [2]. Epidemiyolojik çalışmalar da insan diyetindeki sütün besinsel önemini doğrulamaktadır. Özellikle süt kardiyovasküler hastalıklar, bazı kanser türleri, obezite ve diyabet gibi bazı kronik rahatsızlıkların önlenmesinde etkilidir [3]. İnsanların sütü tüketebilmesi için ısıl işleme maruz kalması gerekir. Isıl işlemle sütün bozulmasına neden olan patojenik ve mikrobiyal faaliyetler engellenmektedir. Bu sebeple sütler, pastörizasyon işleminde 72-80

\footnotetext{
*Sorumlu yazar: mgsucak@gmail.com

Geliş Tarihi: 13.02.2019, Kabul Tarihi: 01.10.2019
} 
${ }^{0} \mathrm{C}$ ve Ultra-Yüksek Sıcaklık (UHT) sütlerde en az $135{ }^{\circ} \mathrm{C}$ 'de 1 sıl işlemlere maruz bırakılır [4,5]. Fakat, yüksek sıcaklığa maruz kalan sütün kalitesinde ve kimyasal içeriğinde değişiklikler oluşmaktadır. Yüksek ısıl işlemlerde sütün kimyasal yapısını oluşturan laktoz, protein, vitamin, enzim, lipit ve kalsiyum/fosfor dengesinin bozulması rapor edilmiştir [6]. Ayrıca, 1sıtılmış sütlerin saklanması sırasında devam eden Maillard reaksiyonunun oluşturduğu yeni maddeler nedeniyle sütün lezzet ve besin değeri kaybı vardır [7]. 2013 yılına göre Türkiye'de inek sütü üretimi 15.977 .838 ton, keçi sütü 415.746 ton, koyun sütü 1.101 .013 ton ve manda sütü 51.947 ton olarak gerçekleşmiştir ve kişi başına düşen süt tüketimi $37.3 \mathrm{~kg}$ olduğu belirtilmiştir [8]. Türkiye İstatistik Kurumunun (TÜİK) Haziran 2019 tarihli yayınına göre ticari süt işletmeleri tarafından içme süt üretiminin 121.735 ton olarak gerçekleştiğini ve 2018 yılına göre \% 2.6 artış gösterdiği rapor edilmiştir [9]. Süt içeriğinde yaklaşık \% $87 \mathrm{su}, \% 3.4$ protein, \% 4.2 yağ, \% 4.6 laktoz, \% 0.1 vitamin ve \% 0.8 mineraller bulunmaktadır [10]. Sütün kimyasal içeriği üzerine hayvanın genetik, beslenme durumu ve çevresel faktörler etkili olmaktadır [11,12]. Doğal sütün fabrikaya gelinceye kadarki süreci, fabrikada uygulanan isıl işlemler gibi birçok faktör süt içeriğinde değişmelere neden olmaktadır. Türkiye'de ticari süt sektörü önemli bir yer tutmaktadır ve birçok marka mevcuttur. Ticari sütler genel olarak tam yağlı, yarım yağlı ve meyveli sütler olarak marketlerde satışa sunulmaktadır. Yaptığımız literatür araştırmasında Türkiye'de çiğ inek sütü ile ticari amaçla fabrikalarda üretilen UHT inek sütlerinin biyokimyasal parametreler yönünden karşılaştırılmasının detaylı olarak yapılmadığı tespit edildi.

Bu çalışmada, çiğ ve ticari amaçla üretilen UHT inek sütlerinin protein, kuru madde, mineral, kazein, laktoz, yağ ve yağsız kuru madde düzeyleri karşılaştırılması amaçlanmıştır.

\section{Materyal ve Metot}

\subsection{Araçlar}

Süt numunelerinin kimyasal parametre seviyeleri FOSS MilkoScan ${ }^{\mathrm{TM}}$ FT-120 (Foss electric, Denmark) ve mineral konsantrasyonları ise ICP-OES Optima 5300 DV (Perkin-Elmer, USA) cihazları kullanılarak yapildi.

\subsection{Süt Numunelerin Temini}

Çiğ inek sütü numuneleri, Türkiye'nin Muş ilinde doğal mera koşullarında ve otlaklarda beslenmiş ineklerden temin edildi. İkinci laktasyon döneminin başında olan 20 adet inekten süt örnekleri toplandı. Süt örnekleri alınmadan önce ineklerin tartımları yapıldı ve inekler 300-400 kg ağırlığında olduğu tespit edildi. Süt numuneleri FAO'nun kriterlerine göre soğuk zincirde laboratuvara getirildi [13]. Türkiye'de yaygın olarak üretimi yapılan UHT ticari inek sütleri Adıyaman ilinde bulunan yerel marketlerden temin edildi. Bu amaçla ticari tam yağlı UHT inek sütünden tam yağlı (TYİS) 6 marka, ticari yarım yağlı UHT inek sütünden (YYİS) 5 marka temin edildi.

\subsection{Analizler}

Çiğ ve ticari inek sütü numuneleri içeriğindeki protein, kazein, yağ, kuru madde, laktoz ve yağsız kuru madde (\%) seviyeleri FOSS cihazı kullanılarak belirlendi [14]. Çiğ ve ticari inek sütü numuneleri mineral analizleri ICP-OES cihazında gerçekleştirildi. ICP-OES cihazında kalsiyum $(\mathrm{Ca})$, demir $(\mathrm{Fe})$, Magnezyum $(\mathrm{Mg})$, Mangan $(\mathrm{Mn})$, fosfor $(\mathrm{P})$, çinko $(\mathrm{Zn})$, potasyum $(\mathrm{K})$ ve sodyum $(\mathrm{Na})$ mineral düzeyleri tespit edildi. $2 \mathrm{~mL}$ süt üzerine $4 \mathrm{~mL} \mathrm{HNO}_{3}\left(\% 65 \mathrm{ah}^{-1}\right)$ ve $1 \mathrm{~mL} \mathrm{HClO}_{4}\left(\% 60 \mathrm{ha}^{-1}\right)$ ilave edildi ve mikrodalga çözme sistemi kaplarına aktarıldı. Çözme işleminden sonra hacim $0.1 \mathrm{M} \mathrm{HNO}_{3}$ ile 20 mL'ye tamamlandı. Kör numunelerde aynı şekilde hazırlandı ve numune çözeltileri ICP-OES cihazında okundu [15]. Tablo 1 de mineral analiz cihazı ICP-OES'in ve Tablo 2 de mikrodalga cihazının çalışma koşulları ayrıntılı olarak verilmiştir [16]. 
Tablo 1. ICP-OES cihazı için çalışma koşulları

\begin{tabular}{|l|c|}
\hline Güç (W) & 1450 \\
\hline Taşıııı gaz hızı $\left(\mathrm{L} \mathrm{min}^{-1}\right)$ & 0.5 \\
\hline Pompa hızı (rpm) & 15 \\
\hline Yardımcı gaz akışı $\left(\mathrm{L} \mathrm{min}^{-1}\right)$ & 0.3 \\
\hline Plazma gaz akışı $\left(\mathrm{L} \mathrm{min}{ }^{-1}\right)$ & 15 \\
\hline Geçikme süresi (sn) & 50 \\
\hline Durulama süresi (her numune arası) $(\mathrm{sn})$ & 30 \\
\hline Stabilizasyon süresi (sn) & 10 \\
\hline Tekrar & 3 \\
\hline
\end{tabular}

Tablo 2. Mikrodalga çözme sistemi programı

\begin{tabular}{|c|c|c|c|}
\hline Basamak & Güç (\%) & Zaman (dk) & Sıcaklık ( $\left.{ }^{\mathbf{O}} \mathbf{C}\right)$ \\
\hline 1 & 95 & 20 & 130 \\
\hline 2 & 85 & 10 & 150 \\
\hline 3 & 40 & 5 & 100 \\
\hline
\end{tabular}

\section{4. İstatistiksel Analiz}

Sütlerin kimyasal ve mineral düzeylerinin istatistiksel değerlendirilmesi SPSS 20.00 yazılım programı kullanılarak hesaplandı. Gruplar arasındaki karşılaştırmada ANOVA varyans analizi kullanıldı. Gruplar arası farklılıkların tespitinde LSD testi kullanıldı. Verilerin analiz sonuçları ortalama \pm standart sapma olarak belirtildi.

\section{Bulgular ve Tartışma}

Tablo 3. Çiğ inek sütleri ve ticari UHT inek sütlerinin mineral düzeyleri $\left(\mathrm{mg} \mathrm{l}^{-1}\right)$

\begin{tabular}{|l|c|c|c|}
\hline Elementler & Çiğ İnek Sütü Grubu & UHT TYIS Grubu & UHT YYiS Grubu \\
\hline $\mathrm{Ca}$ & $1183.75 \pm 82.31$ & $959 \pm 31^{\mathrm{c}}$ & $1146 \pm 65$ \\
\hline $\mathrm{Fe}$ & $0.83 \pm 0.09$ & $0.38 \pm 0.06^{\mathrm{c}}$ & $0.47 \pm 0.09^{\mathrm{c}}$ \\
\hline $\mathrm{Mg}$ & $104.00 \pm 9.30$ & $94.33 \pm 4.54$ & $109.00 \pm 4.76$ \\
\hline $\mathrm{Mn}$ & $0.32 \pm 0.02$ & $0.24 \pm 0.01^{\mathrm{b}}$ & $0.28 \pm 0.01$ \\
\hline $\mathrm{P}$ & $916.25 \pm 78.33$ & $750 \pm 15^{\mathrm{b}}$ & $882 \pm 31$ \\
\hline $\mathrm{Zn}$ & $4.36 \pm 0.57$ & $3.92 \pm 0.16$ & $4.64 \pm 0.32$ \\
\hline $\mathrm{K}$ & $1200.25 \pm 74.63$ & $1010 \pm 16^{\mathrm{c}}$ & $1203 \pm 49$ \\
\hline $\mathrm{Na}$ & $297.62 \pm 33.50$ & $325 \pm 16$ & $369 \pm 24^{\mathrm{b}}$ \\
\hline
\end{tabular}

Çiğ inek sütü grubuna göre karşılaştırma: a:p $<0.05$, b:p $<0.01$, c:p $<0.001$.

TYIS: Tam Yağlı İnek Sütü, YYİS: Yarım Yağlı İnek Sütü

Çiğ inek sütleri ve ticari UHT inek sütlerinin mineral düzeyleri Tablo 3 de verilmiştir. Kalsiyum mineral seviyeleri bakımından yapılan karşılaştırmada çiğ inek sütü grubunun en yüksek Ca seviyesine sahip olduğu, bunu sırasıyla YYİS ve TYIS grubunun takip ettiği görülmüştür. Çiğ inek sütü Ca düzeyinin TYIS sütü grubundan istatistiksel olarak yüksek çıktı̆̆ belirlenirken ( $p<0.001)$, Çiğ inek sütü $\mathrm{Ca}$ düzeyi ile YYİS grubu arasında istatistiksel fark olmadığı belirlendi ( $\mathrm{p}>0.05)$. Demir mineral seviyeleri bakımından yapılan karşılaştırmada ise Çiğ inek sütü grubunun en yüksek Fe seviyesinde olduğu, TYİS ve YYİS grupları Fe düzeylerinin istatistiksel olarak Çiğ inek sütü grubuna göre azaldığı belirlendi ( $\mathrm{p}<0.001)$. Çiğ inek sütü P ve K mineral düzeyleri TYİS grubundan yüksek çıtığı tespit edildi $(\mathrm{p}<0.01, \mathrm{p}<0.001)$. Na mineral seviyeleri bakımından yapılan karşılaştırmada ise YYIS grubunun Na seviyesi Çiğ inek sütü grubundan yüksek çıktı̆̆ tespit edildi ( $p<0.01)$. TYİS grubu Na minerali düzeyi Çiğ inek sütü grubuna göre nispi artış gözlendi ( $p>0.05)$. Mn mineral düzeyi en yüksek Çiğ inek sütü grubunda olduğu belirlendi. Çiğ inek sütü Mn seviyesine göre TYIS grubunda istatistiksel olarak azaldığ 1 tespit edilirken $(\mathrm{p}<0.01)$, Çiğ inek sütü Mn seviyesine göre YYİS grubunda bu azalıs nispi oranda olduğu belirlendi ( $>0.05$ ). Pakistan'da yapılan bir çalışmada çiğ inek sütü ile dört farklı ticari 
UHT sütleri arasındaki mineral düzeyleri karşılaş̧ırılmıştır. Çiğ inek sütü mineralleri Na 20, K 152, Ca 680 ve $\mathrm{Mg} 205 \mathrm{mg} \mathrm{l}^{-1}$ düzeylerinde tespit edilirken, UHT sütlerde bu minerallerin değerleri Na 55-80, $\mathrm{K}$ 115-128, Ca 755- 823 ve Mg 109-187 $\mathrm{mg} \mathrm{l}^{-1}$ düzeylerinde tespit etmişlerdir. Ayrıca UHT sütlerin içeriğindeki $\mathrm{K}$ ve $\mathrm{Mg}$ mineral düzeyleri çiğ inek süt grubuna göre azalırken, $\mathrm{Na}$ ve $\mathrm{Ca}$ mineral düzeylerinde artış olduğunu rapor etmişlerdir [17]. Mısır'da yapılan araştırmada, çiğ inek sütü ile UHT inek sütleri $\mathrm{Fe}, \mathrm{Mn}$ ve $\mathrm{Zn}$ düzeyleri tespit edilmiştir. Araştırmada, çiğ inek sütü minerallerinden $\mathrm{Fe}$ 0.682 , Mn 0.056 ve $\mathrm{Zn} 3.146 \mathrm{mg} \mathrm{kg}^{-1}$ düzeylerinde tespit edilirken, UHT inek sütlerinde bu oran $\mathrm{Fe}$ $0.572, \mathrm{Mn} 0.047$ ve Zn $2.828 \mathrm{mg} \mathrm{kg}^{-1}$ düzeylerinde bulmuşlardır [18]. Bakircioglu ve ark., 2018 y1lında Türkiye'de çiğ inek sütlerinde Ca düzeyi 950, Mg 429, Na 332, K 1645, Fe 3.1, Mn 0.049 ve Zn 3.4 $\mathrm{mg} \mathrm{kg}^{-1}$ düzeylerinde tespit ederken, UHT inek sütlerinde ise Ca 932, $\mathrm{Mg}$ 423, $\mathrm{Na} 339, \mathrm{~K} \mathrm{1642,} \mathrm{Fe} 2.2$, Mn 0.061ve Zn $3.5 \mathrm{mg} \mathrm{kg}^{-1}$ düzeylerinde tespit etmişlerdir [19].Yapılan bu çalışmalarda, ticari UHT süt içeriğindeki bazı mineral düzeylerinde değişikliklerin olduğu gözlendi. Bu farklılıkların nedenleri olarak hayvanın genetik, beslenme durumu ve çevresel faktörlerden kaynaklandığı rapor edilmiştir [11,12]. Çalışmamızda, UHT inek sütleri içreğinde Na düzeyi yüksek çıktığı tespit edilirken, diğer mineral düzeylerinde ise azalma gözlendi. İnsan metabolizması için gerekli olan mineralleri birçok besinsel kaynaktan almaktayız. Metabolizmamızda özellikle enzim aktivitelerinin ve immünolojik reaksiyonlar düzenlenmesinde rol alan bu mineraller metabolizmamızda birçok hastalığa karşı pozitif etkinlikleri olduğu da bildirilmiştir $[20,21]$. Fe insan ve hayvan metabolizması için gerekli bir mineraldir. Özellikle hemoglobinin yapısı, bağışıklık ve enerji sistemi için çok önemlidir [22]. Mn ve Zn'nun antioksidan enzimlerin aktivitesinde ve hücrede radikallere karşı savunmada önemli fonksiyonları vardır [23,24]. $\mathrm{Mg}$ metabolizmada üç yüzden fazla enzimin yapısında kofaktör olarak önemli rol oynar. Kalsiyum ise kemik gelişimi için çok önemlidir [25]. Sütün yapısında bulunan kimyasal moleküllere özellikle hayvanların beslenme şartları, çevresel faktörler ve hayvanın genetik yapısı etkili olmaktadır [12].

Tablo 4. Çiğ inek sütleri ve ticari UHT sütlerin kimyasal parametreleri (\%)

\begin{tabular}{|l|c|c|c|}
\hline $\begin{array}{l}\text { Kimyasal } \\
\text { parametreler }\end{array}$ & $\begin{array}{c}\text { Çĭ̆ İnek Sütü } \\
\text { Grubu }\end{array}$ & $\begin{array}{c}\text { UHT TYÍS } \\
\text { Grubu }\end{array}$ & $\begin{array}{c}\text { UHT YYIS } \\
\text { Grubu }\end{array}$ \\
\hline Kuru madde & $12.90 \pm 0.32$ & $10.92 \pm 0.25^{\mathrm{c}}$ & $9.98 \pm 0.31^{\mathrm{c}}$ \\
\hline Yağsız kuru madde & $9.29 \pm 0.20$ & $7.49 \pm 0.19^{\mathrm{c}}$ & $7.90 \pm 0.38^{\mathrm{c}}$ \\
\hline Yăg & $3.61 \pm 0.30$ & $2.99 \pm 0.01^{\mathrm{a}}$ & $1.57 \pm 0.02^{\mathrm{c}}$ \\
\hline Protein & $3.66 \pm 0.16$ & $2.71 \pm 0.07^{\mathrm{c}}$ & $2.73 \pm 0.06^{\mathrm{c}}$ \\
\hline Laktoz & $4.62 \pm 0.11$ & $4.00 \pm 0.10^{\mathrm{b}}$ & $4.01 \pm 0.22^{\mathrm{b}}$ \\
\hline Kazein & $2.80 \pm 0.12$ & $1.99 \pm 0.07^{\mathrm{c}}$ & $2.21 \pm 0.13^{\mathrm{a}}$ \\
\hline
\end{tabular}

Çiğ inek sütü grubuna göre karşılaştırma a:p $<0.05$, b:p $<0.01$, c:p $<0.001$.

TYİS: Tam Yağlı İnek Sütü, YYİS: Yarım Yağlı İnek Sütü

Çiğ inek sütleri ve ticari UHT sütlerin kimyasal parametreleri Tablo 4 de belirtilmiştir. Kuru madde, protein ve yağsız kuru madde düzeyleri Çiğ inek sütü grubunda en yüksek seviyede olduğu, TYIS ve YYIS gruplarında ise azaldığı belirlendi $(\mathrm{p}<0.001)$. Ayrıca, Çiğ inek sütü grubuna göre TYIS ve YYİS grupları yağ, laktoz ve kazein düzeylerindeki azalış istatistiksel olarak tespit edildi $(p<0.05)$. Enb ve ark. Çiğ inek sütleri ile bu sütten elde edilen ürünlerin kimyasal bileşenleri tespiti yapmışlardır. Çalışmalarında çiğ inek sütü yăg \% 3.20, protein \% 3.20, kuru madde $\% 12.10$ ve laktoz $\% 5.00$ düzeylerinde tespit edilirken, UHT sütte ya ğ \% 3.00, protein \% 3.30, kuru madde $\% 11.90$ ve laktoz \% 4.70 düzeylerinde tespit etmişlerdir [18]. Imran ve ark. tarafından yapılan başka bir çalışmada, çiğ inek sütü kimyasal bileşenlerinden kuru madde \% 13.5, protein \% 3.28, kazein \% 2.46 ve laktoz \% 4.38 düzeylerinde tespit eder iken, inceledikleri dört ticari markalı UHT sütlerde ise kuru madde \% 13.7 15.2, protein \% 2.59-4.49, kazein \% 1.94-3.36 ve laktoz \% 3.49-4.21 düzey araliklarında gözlemlemişlerdir [17]. Çalışmamızda özellikle ticari UHT sütlerde yağ ve protein düzeyleri çiğ inek sütlerine göre azaldığı görüldü. Yukarıda belirtilen literatürlerde kimyasal parametrelerin birbirine yakın çıktığı görülmektedir. Pestana ve ark. Çiğ, pastörize ve UHT sütlerin kimyasal bileşenlerindeki farklıları tespit çalışmasında önemli sonuçlar rapor etmişlerdir. Çiğ süt, pastörize ve UHT süt protein düzeylerini sirasiyla $\% 3.20, \% 3.19, \% 3.20$, yağ düzeylerini $\% 3.58, \% 3.07, \% 3.15$, laktoz düzeylerini $\% 4.28$, $\%, 4.25, \% 4.27$, kuru madde düzeylerini $\% 12.06, \% 11.54, \% 11.56$ ve yağsız kuru madde düzeylerini $\%$ 8.47, \% 8.47, \% 8.41 olarak rapor etmişlerdir. Çalışmalarında, çiğ süt yağ ve kuru madde düzeylerine göre pastörize ve UHT sütlerinde istatistiksel azalma olduğunu belirtilirken, protein ve laktoz 
düzeylerinde farklılı̆̆ın olmadığı belirtilmiştir [26]. Sütün kimyasal yapısını oluşturan laktoz, protein, vitamin, enzim, lipit ve kalsiyum/fosfor dengesinin yüksek ısıl işlemlerle oranlarında değişimler olduğu rapor edilmiştir [6]. Bu şartlar dışında sütün kimyası üzerine en önemli etkenlerden biride sütteki mikrobiyal faaliyetlerdir. Doğal sütün çiğ olarak tüketilmesi insan metabolizmasında hastalıklara neden olduğu bildirilmiştir. Bu nedenlerden dolayı sütün tüketilmeden önce 1sıtılması önerilmektedir. Ayrıca, doğal sütün 1sıtılması besin değerini önemli ölçüde değiştirmediği rapor edilmiştir [1].

\section{Sonuçlar ve Öneriler}

Çalışmamızda, doğal inek sütü $\mathrm{Ca}, \mathrm{Fe}, \mathrm{Mn}, \mathrm{P}$, protein, yağ, kuru madde ve yağsız kuru madde düzeylerine göre ticari sütlerde azalma olduğu tespit edildi. Her ne kadar ticari sütlerin kimyasal bileşenlerinde azalmalar tespit edilmiş olsa da içeriğindeki kimyasal bileşen düzeyleri seviyesi insan metabolizması için gerekli düzeydedir. Ayrıca, doğal sütlerin tüketiminin insan metabolizmasında oluşturabileceği mikrobiyal olumsuzluklar göz önüne alındığında, ticari sütlerin tüketilmesinin daha anlamlı olacağını düşünmekteyiz.

\section{Teşekkür}

Bu çalışmayı FEFYL/2015-0002 nolu proje ile destekleyen Adıyaman Üniversitesi Bilimsel Araştırma Projeler Birimi’ne teşekkür ederiz.

\section{Yazarların Katkısı}

Çalışmada tüm yazarlar eşit oranda katkı sunmuştur.

\section{Çıkar Çatışması Beyanı}

Yazarlar arasında herhangi bir çıkar çatışması bulunmamaktadır.

\section{Araştırma ve Yayın Etiği Beyanı}

Yapılan çalışmada, araştırma ve yayın etiğine uyulmuştur.

\section{Kaynaklar}

[1] Claeys W.L., Cardoen S., Daube G., Block J.D., Dewettinck K., Dierick K., Zutter L.D., Huyghebaert A., Imberechts H., Thiange P., Vandenplas Y., Herman L. 2013. Raw or heated cow milk consumption: Review of risks and benefits. Food Control, 31: 251-262.

[2] Claeys W.L., Verraes C., Cardoen S., De Block J., Huyghebaert A., Raes K., Dewettinck K., Herman L. 2014. Consumption of raw or heated milk from different species: An evaluation of the nutritional and potential health benefits. Food Control, 42: 188-201.

[3] Pereira P.C. 2014. Milk nutritional composition and its role in human health. Nutrition, 30: 619627.

[4] Lewis M.J., Deeth H.C. 2009. Heat Treatment of Milk. In: Milk Processing and Quality Management, Tamime. A.Y. (Ed.), Wiley-Blackwell, Oxford, UK.

[5] https://members.wto.org/crnattachments/2018/SPS/TUR/18_2510_00_x.pdf. (Erişim Tarihi: 15.12.2018).

[6] Sakkas L., Moutafi A., Moschopoulou E., Moatsou G. 2014. Assessment of heat treatment of various types of milk. Food Chem., 159: 293-301.

[7] Elliott A.J., Datta N., Amenu B., Deeth H.C. 2005. Heat-induced and other chemical changes in commercial UHT milks. J. Dairy Res., 72: 442-446.

[8] Köseman A., Şeker İ. 2015. Current Status of Cattle, Sheep and Goat Breeding in Turkey. Van Veterinary Journal, 26 (2): 111-117. 
[9] TUIK, 2019. Türkiye İstatistik Kurumu verileri. Süt ve Süt Ürünleri Üretimi. https://ulusalsutkonseyi.org.tr/tuik-sut-ve-sut-urunleri-uretim-istatistikleri-haziran-2019-2651/ (Erişim tarihi:16.08.2019).

[10] Mansson H.L. 2008. Fatty acids in bovine milk fat. Food \& Nutrition Research, 52 (1): 1821

[11] Caroli A.M., Chessa S., Erhardt G.J. 2009. Invited review: Milk protein polymorphisms in cattle: Effect on animal breeding and human nutrition. J Dairy Sci., 92: 5335-5352.

[12] Kalac P., Samkova E. 2010. The effects of feeding various forages on fatty acid composition of bovine milk fat: A review. Czech Journal of Animal Science, 55 (12): 521-37.

[13] FAO, 2011. Molecular genetic characterization of animal genetic resources. FAO Animal Production and Health Guidelines, Rome, No: 9.

[14] Chemists A.O.O.A, Horwitz W. 2000. Official Methods of Analysis of the Association of Official Analytical Chemists, 17 (1-2).

[15] Ciftci H., Ozkaya A., Kariptas E. 2009. Determination of fatty acids, vitamins and trace elements in Pistacia terebinthus coffee. Journal of Food, Agriculture and Environment, 7: 72-74.

[16] Özkaya A., Ertürk A.S., Sucak M.G., Ağyar O., Yılmaz E. 2017. Saanen Keçi Sütünün Bazı Biyokimyasal Özelliklerinin Belirlenmesi. Iğdır Üni. Fen Bilimleri Enst. Der., 7 (4): 123-129.

[17] Imran M., Khan H., Hassan S.S., Khan R. 2008. Physicochemical characteristics of various milk samples available in Pakistan. J Zhejiang Univ Sci B, 9 (7): 546-551.

[18] Enb A., Donia M.A.A., Abd-Rabou N.S., Abou-Arab A.A.K., El-Senaity M.H. 2009. Chemical Composition of Raw Milk and Heavy Metals Behavior During Proces sing of Milk Products. Global Veterinaria, 3 (3): 268-275.

[19] Bakircioglu D., Topraksever N.,Yurtsever S., Kizildere M., Kurtulus Y.B. 2018. Investigation of macro, micro and toxic element concentrations of milk and fermented milks products by using an inductively coupled plasma optical emission spectrometer, to improve food safety in Turkey. Microchemical Journal, 136: 133-138.

[20] Selvaraju R., Raman R.G., Narayanaswamy R., Valliappan R., Baskaran R. 2009. Trace element analysis in hepatitis B affected human blood serum by inductively coupled plasma-atomic emission spectroscopy (ICP-AES). Romanian Journal of Biophysics, 19: 35-42.

[21] Emsley J. 2011. Nature's building blocks: an A-Z guide to the elements. Oxford, UK: Oxford University Press, 1-699.

[22] Ullah R., Khader J.A., Hussain I., AbdElsalam N.M., Talha M., Khan N. 2012. Investigation of macro and micro-nutrients in selected medicinal plants. African Journal of Pharmacy and Pharmacology, 6 (25): 1829-1832.

[23] Ayodele J.T., Bayero A.S. 2010. Manganese concentrations in hair and fingernail of some Kano inhabitants. Journal of Applied Sciences and Environmental Management, 4 (1): 17-21.

[24] Bhowmik D., Chiranji B.C., Kumar K.P. 2010. Apotential medicinal importance of zinc in human health and chronic disease. Journal of Pharmaceutical and Biomedical Sciences, 1: 5-11.

[25] Nestares T., Diaz-Castro J., Alferez M.J.M., Lopez- Aliaga I., Barrionuevo M., Campos M.S. 2008. Calcium-enriched goat milk, in comparison with similarly enriched cow milk, favours magnesium bioavailability in rats with nutritional ferropenic anaemia. Journal of the Science of Food and Agriculture, 88: 319-327.

[26] Pestana J.M., Gennari A., Monteiro B.W., Lehn D.N., Volken de Souza C.F. 2015. Effects of Pasteurization and Ultra-High Temperature Processes on Proximate Composition and Fatty Acid Profile in Bovine Milk. American Journal of Food Technology, 10 (6): 265-272. 